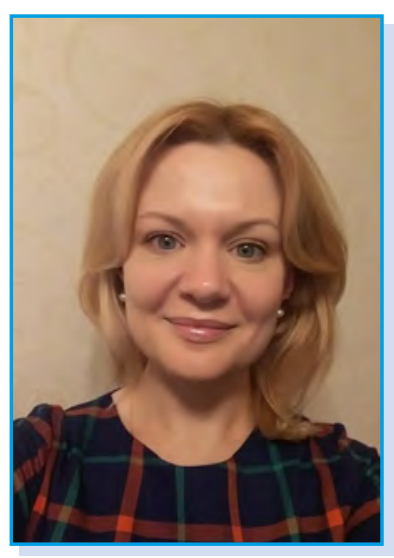

Людмила Нестеренко - кандидат наук з державного управління, доцент, доцент кафедри англійської мови факультету гуманітарних наук Національного університету «Києво-Могилянська академія», м. Київ, Україна.

Коло наукових інтересів: якість освіти; якість викладання іноземної мови за професійним спрямуванням; дослідження теоретичних, методичних та психологічних особливостей викладання англійської мови за професійним спрямуванням у вищих навчальних закладах; зміст професійної діяльності викладача іноземної мови; сучасні методики та технології викладання іноземної мови за професійним спрямуванням у вищих навчальних закладах.

l.nesterenko@ukma.edu.ua,lyudm.nesterenko@gmail.com

https://orcid.org/0000-0003-2131-1329

\author{
УДК 37.025.2 \\ https://doi.org/10.32405/2411-1317-2021-4-206-213
}

\title{
АКТИВНЕ СЛУХАННЯ ЯК СПОСІБ ПІДВИЩЕННЯ ЕФЕКТИВНОСТІ КОМУНІКАЦІЇ У ПРОЦЕСІ НАВЧАННЯ АНГЛІЙСЬКОЇ МОВИ ЗА ПРОФЕСІЙНИМ СПРЯМУВАННЯМ У ЗВО
}

У статті активне слухання розглядається як один із ключових інструментів, спрямованих на вдосконалення комунікації у процесі викладання іноземної мови (на прикладі англійської мови) у системі вищої освіти; охарактеризовані основні психологічні особливості здійснення комунікації в процесі викладання іноземної мови за професійним спрямуванням та окреслені основні підходи щодо вдосконалення володіння англійською; проаналізовані різноманітні підходи до класифікації видів активного слухання. До основних видів активного слухання віднесені: емпатійне слухання, критичне слухання, пасивне слухання та активне слухання. На основі теоретичного аналізу видів активного слухання та вимог до викладання іноземної мови за професійним спрямуванням у ЗВО визначені та охарактеризовані основні вимоги до використання активного слухання у процесі викладання іноземної мови. Окреслені переваги дотримання соціальнопсихологічних (встановлення психологічного контакту; атрактивність; виявлення партнерської позиції; виявлення емпатійності; щирість у спілкуванні) та когнітивно-контекстуальних (поєднання теоретичних та емпіричних матеріалів у момент викладення власної позиції; використання раціональних та емоційних звернень до аудиторії; використання ефекту новизни; дотримання порядку подачі матеріалу; здійснення повторення найбільш важливого матеріалу) вимог у процесі викладання іноземної мови за професійним спрямуванням у ЗВО. Сформульовані практичні рекомендації щодо використання вербальних та невербальних способів активного слухання. Доведено, що активне слухання сприяє забезпеченню позитивної атмосфери на заняттях з іноземної мови, мінімізації ймовірності конфліктних ситуацій та формуванню поваги й довіри між учасниками освітнього процесу.

Ключові слова: викладання іноземної мови за професійним спрямуванням; комунікація; активне слухання; інструменти активного слухання; вища освіта; ефективність; якість освіти. 
Постановка проблеми в загальному вигляді та ії зв’язок з важливими науковими та практичними завданнями. Однією з найважливіших умов забезпечення ефективного функціонування системи вищої освіти в Україні в умовах розвитку незалежної, демократичної та правової держави $є$ наповнення новим змістом професійної діяльності викладачів закладів вищої освіти, адже від їх компетентності залежить ефективна реалізація функцій та завдань, які постають перед системою вищої освіти. Нині суттєво зростає значення комунікації як способу забезпечення якості вищої освіти, оскільки через комунікацію реалізуються основні функції освіти.

Відтак, пошук ефективних механізмів удосконалення комунікації у процесі викладання іноземної мови за професійним спрямуванням зумовлює актуальність цієї статті. Адже якісна комунікація стає важливим стратегічним ресурсом, наявність якого веде до суттєвих надбань та якісних змін у системі освіти.

Аналіз останніх досліджень і публікацій з проблеми. Усе частіше використання активного слухання розглядається як спосіб покращення якості викладання іноземної мови за професійним спрямуванням. Дана теза знаходить підтвердження у роботах Д. Біна (Bean, 1996), Н.Д. Гальскової (Гальскова, 2000), О.І. Локшиної (Локшина, 2019), Д. Річардаса (Richards, 2005), С. Савіньона (Savignon, 2001), О. Б. Тарнапольского (Тарнопольский, 2019) та Д. Шульца (Schultz, 2009). Системний наліз наукових праць А. А. Леонтьєва (Леонтьев, 2003), Г.С. Нікіфорова (Никифорова, 2004) та Л.О. Нестеренко (Нестеренко, 2014, 2016) дозволяє стверджувати, що активне слухання суттєво допомагає зрозуміти, оцінити і запам'ятати інформацію, отриману від учасників освітніх взаємодій. Використання прийомів активного слухання традиційно спонукає учасників навчального процесу до відповідей, скеровує діалог у потрібному напрямку і мінімізує ймовірність неправильного розуміння чи помилкової інтерпретації інформації, отриманої від співрозмовника (студентом/студентами від викладача, викладачем від студента/ студентів, студентом від студента/студентів, студентами від студента/студентів). Утім, у працях зазначених вище дослідників, відсутнє науково-практичне обгрунтування використання активного слухання як окремого способу удосконалення комунікації у процесі викладання іноземної мови за професійним спрямуванням.

Формулювання цілей статті. Тож, основними цілями цієї статті є:

1) аналіз особливостей комунікації між учасниками освітніх взаємодій у процесі викладання іноземної мови за професійним спрямуванням;

2) систематизація умов та прийомів використання активного слухання у процесі викладання іноземної мови за професійним спрямуванням;

3) визначення способів використання активного слухання у процесі викладання англійської мови за професійним спрямуванням;

4) окреслення вербальних (лексичних та граматичних) і невербальних способів використання активного слухання у процесі викладання іноземної мови за професійним спрямуванням.

Отже, науково-практичне обгрунтування використання активного слухання як способу підвищення ефективності комунікації у процесі викладання іноземної мови за професійним спрямуванням виступає основною метою статті.

Зважаючи на полідетермінованість та структурну складність активного слухання вважаємо, що методологічною основою впливу досліджуваного нами феномену на вдосконалення комунікації у ЗВО можуть бути гуманістичний та системний принципи (Леонтьев, 2003), у поєднанні 3 принципом єдності свідомості та діяльності (Никифорова, 2004). Адже основу таких принципів становить сукупність вихідних концептуальних уявлень, цільових установок, методик, психодіагностичних і психолого-технологічних засобів, які можуть забезпечити глибоке та цілісне розуміння пізнання професійної діяльності викладача у цілому та способів вдосконалення комунікативної компетентності, зокрема. Пріоритетність вищезазначених принципів походить також від переорієнтації організаційних структур системи вищої освіти України на ідеї гуманізації професійної діяльності, що виявляються у подальшій можливості створення передумов для побудови стосунків між учасниками освітніх взаємодій на основі партнерства з урахуванням їх 
індивідуально-психологічних особливостей, i, відповідно, створенні гідних умов для реалізації творчого потенціалу та особистісного розвитку усіх задіяних в освітньому процесі осіб.

Виклад основного матеріалу. Останнім часом у науковій спільноті (Гальскова, 2000), (Локшина, 2019), (Savignon, 2001), (Тарнопольский, 2019) (Нестеренко, 2016) спостерігається підвищений інтерес до проблеми якості освіти в цілому та вдосконалення професійної компетентності викладачів закладів вищої освіти зокрема. Теза знаходить підтвердження в низці нормативноправових документів, що регулюють діяльність закладів вищої освіти України. Так, у Стратегії Національного агентства із забезпечення якості вищої освіти визначено, що «Забезпечення якості вищої освіти $є$ вимогою сучасності, ключовим принципом Болонської декларації та незаперечним пріоритетом для академічної спільноти і державної освітньої політики країн Європи та інших розвинених країн світу» (Стратегія, 2018, с. 1).

Питання якості освіти відображені і в Положенні про акредитацію освітніх програм (Наказ № 977, 2019), за якими здійснюється підготовка здобувачів вищої освіти. Згідно з Положенням проведення оцінювання якості освітніх програм має здійснюватися на основі принципів прозорості та відкритості за допомогою чітко визначених критеріїв.

Відтак для забезпечення відповідності критеріям якості вищої освіти, що визначені нормативно-правовими документами на національному рівні, заклади вищої освіти, своєю чергою, формулюють власні політики щодо забезпечення якості вищої освіти на високому рівні. Так, наприклад, у Національному університеті «Києво-Могилянська академія», у Концепції забезпечення якості освіти в НаУКМА (Наказ № 518, 2016) зазначено, що забезпечення високої якості освітнього процесу є одним із пріоритетних напрямків діяльності НаУКМА. У Концепції чітко визначені та охарактеризовані мета і завдання внутрішньої системи забезпечення якості освітньої діяльності (Наказ № 518, 2016, с. 2-3), організаційна структура з управління якістю освіти в НаУКМА (Наказ № 518, 2016, с. 4), контроль якості освітньої діяльності (Наказ № 518, 2016, с. 4), а також схема внутрішнього та зовнішнього контролю якості освіти в НаУКМА (Наказ № 518, 2016, с.5-6).

Комунікативна компетентність викладача закладу вищої освіти визначена як важлива якісна характеристика загальної професійної компетентності науково-педагогічного працівника у Професійному стандарті на групу професій «Викладачі закладів вищої освіти» (Наказ № 610, 2021) від 23 березня 2021. Адже, з одного боку, ступінь сформованості комунікативних навичок викладача 3ВО значною мірою залежить від структури освітньої організації, від її цілей та потреб учасників освітніх взаємодій у професійній інформації, а з іншого боку рівень комунікативної компетентності викладача ЗВО суттєво впливає на стан комунікативних навичок інших учасників освітнього процесу в системі вищої школи та визначає якісні характеристики результатів навчання.

3 огляду на зазначене вище, залучення досягнень психологічної науки може розглядатися як один із способів пришвидшення якісних змін в освітній системі. Так, аналіз праць Л.М. Карамушки (Карамушка, 2003) та Л.Е. Орбан-Лембрик (Орбан-Лембрик, 2002) переконливо засвідчує, що багатогранність такого психологічного феномену, як комунікація та його складна структура водночас визначають і основні шляхи його вдосконалення. Одним із способів удосконалення професійної комунікації виступає саме активне слухання, яке, власне, і допомагає уникнути непорозумінь та пересвідчитися, що було досягнуто основну комунікативну мету. I процес викладання англійської мови за професійним спрямуванням може виступити яскравим підтвердженням висловленої вище тези. Активне слухання може стати одним із найбільш адекватних способів, що дозволить підвищити ефективність комунікації в аудиторії та якість викладання іноземної мови за професійним спрямуванням

Праці Н.Д. Гальскової (Гальскова, 2000), О.І. Локшиної (Локшина, 2019), Д. Річардаса (Richards, 2005), О.Б. Тарнапольского (Тарнопольский, 2019) дозволяють стверджувати, що студенти підходять до вивчення іноземної мови через сферу діяльності, яка вже відома для них. Це означає, що вони можуть одразу використовувати вивчений матеріал у роботі та навчанні. Тому метою дисципліни «Англійська мова за професійним спрямуванням» традиційно висту- 
пає формування необхідної комунікативної спроможності у сферах професійного та ситуативного спілкування в усній і письмовій формах, навичок практичного володіння іноземною мовою в різних видах мовленнєвої діяльності в обсязі тематики, що обумовлена професійними потребами; оволодіння новітньою фаховою інформацією через іноземні джерела тощо, окрім основних завдань дисципліни, які традиційно полягають в навчанні, розвиткові та удосконаленні різноманітних видів мовленнєвої діяльності: аудіювання, говоріння, діалогічного мовлення, читання, письма та перекладу.

Так, наприклад, у Національному університеті «Києво-Могилянська Академія», робоча програма (Нестеренко, 2019) для студентів другого року навчання з англійської мови за професійним спрямуванням, допомагає не лише вдосконаленню мовленнєвих та мовних навичок з англійської мови, а й забезпечує умови, що сприяють засвоєнню фахових дисциплін. Адже значна кількість фахової літератури викладена англійською мовою, і деякі фахові предмети в Університеті також викладаються англійською мовою.

Сама ж програма курсу «Англійська мова за професійним спрямуванням» (Нестеренко, 2019, с. 5) у Національному університеті «Києво-Могилянська Академія» базується на комунікативному підході до викладання іноземної мови (в основу розробки програми такого типу покладено теорію комунікативного навчання мові) і належить до нового типу навчальних програм, де на перший план висувається завдання практичного активного оволодіння англійською мовою.

Відповідно, програма орієнтована на розвиток спеціалізованих мовних і мовленнєвих навичок, умінь фахового спрямування та вироблення комунікативної компетенції студентів на рівні, що умовно називається «вище-середній» («upper-intermediate»).

Саме тому під час вивчення англійської мови за професійним спрямуванням, окрім суто лінгвістичних компетенцій, студенти формують такі компетенції, як здатність планувати роботу та керувати часом; здатність працювати як у команді, так і самостійно; уміння орієнтуватися в різноманітних лінгвістичних концепціях, критично їх оцінювати та використовувати їхні здобутки у власних дослідженнях; здатність самостійно опановувати нові знання, критично оцінювати набутий досвід тощо.

3 огляду на вищезазначене, особливого значення набувають здобутки психологічної науки щодо особливостей спілкування між викладачем та студентами та психологічні способи підвищення ефективності такого спілкування. Аналіз наукового доробку Н.Д. Гальскової (Гальскова, 2000), дозволяє стверджувати, що чітке формулювання цілей іншомовної мовленнєвої діяльності, соціальна і професійна спрямованість цієї діяльності, задоволеність студентів при вирішенні приватних завдань, формування у студентів уміння творчо підходити до вирішення приватних завдань, сприятливий психологічний клімат у навчальному колективі сприяють якісному викладанню іноземної мови за професійним спрямуванням та $є$ пріоритетними. Відповідно набувають нового значення і умови, які можуть забезпечити забезпечення викладання іноземної мови за професійним спрямуванням на належному рівні.

Традиційно для оптимізації передачі інформації у процесі безпосередньої комунікації учасники професійної комунікації дотримуються певних вимог, які умовно можна розподілити на дві групи:

- соціально-психологічні (встановлення психологічного контакту; атрактивність; виявлення партнерської позиції; виявлення емпатійності; щирість у спілкуванні);

- когнітивно-текстуальні (поєднання теоретичних та емпіричних матеріалів у момент викладення власної позиції; використання раціональних та емоційних звернень до аудиторії; використання ефекту новизни; дотримання порядку подачі матеріалу; здійснення повторення найбільш важливого матеріалу).

Наш досвід засвідчує, що в комунікації під час викладання іноземної мови за професійним спрямуванням учасники освітніх взаємодій традиційно використовують такі види слухання:

- емпатичне слухання - вміння розуміти почуття, емоції мовця,уявляти себе на місці співрозмовника, співпереживати йому; 
- критичне слухання - цілеспрямований аналіз отриманої інформації та ії̈ критичне сприйняття, розуміння, що дозволяє зважити всі «за» і «проти», погодитися або не погодитися зі співрозмовником;

- пасивне слухання - мінімальне втручання в монолог співрозмовника;

- активне слухання - максимальне встановлення зворотного зв'язку зі співрозмовником; такий вид слухання поєднує емпатійне, пасивне та критичне слухання.

Змістовний аналіз видів слухання дозволяє стверджувати, що саме використання прийомів активного слухання у процесі викладання іноземної мови за професійним спрямуванням, дозволяє забезпечити використання основних умов вдосконалення ефективності комунікації між основними учасниками.

До найбільш поширених прийомів активного слухання Л. М. Карамушка (Карамушка, 2003) та Л.Е. Орбан-Лембрик (Орбан-Лембрик, 2002) традиційно відносять: паузи, уточнення, перефраз, переказ, розвиток думки, повідомлення про сприйняття, повідомлення про сприйняття себе, повідомлення про хід розмови тощо.

Аналіз прийомів активного слухання, у свою чергу, дозволяє окреслити вимоги до активного слухання у процесі викладання іноземної мови за професійним спрямуванням:

- максимальна концентрація на висловлюванні співрозмовника та тимчасове уникнення критичних суджень;

- емпатія до співрозмовника;

- увага до невербальних проявів комунікації;

- заохочення співрозмовника дозволяє налаштуватися на спілкування.

Практична реалізація вищезазначених вимог у процесі викладання іноземної мови за професійним спрямуванням (на прикладі англійської мови) може бути досягнена за умови використання різноманітних невербальних (усмішка, кивання, доброзичливий погляд) та вербальних способів комунікації. До вербальних проявів можна віднести наступні лексичні та граматичні засоби:

- «питання-луна» (echo questions): «I think ...» - «Do you?»;

- розділові питання (tag questions): «You think ..., don’t you?»;

- ррази, що демонструють інтерес до слухача: «Go on!», «I am listening to you!», «That’s it»;

- повторення почутої раніше думки: «Do уоu mean that ...?.», «In other words...»;

- відображення (чи віддзеркалення) - уміння зрозуміти те, що складно передати словами. Для демонстрації відображення можна вживати фрази: «Do you feel that ...?», «Do you think that ...?»;

- узагальнення почутої інформації. Досвідчений викладач обов'язково підведе підсумок, тим самим даючи зрозуміти, що уважно слухав співрозмовника і зрозумів його основну думку. Це фрази: «I guess, I understand that you ...», «It seems to me that the key point is ...».

- резюмування. Цей прояв активного слухання найбільш ефективно допомагає домогтися точного розуміння почутого (сказаного) співрозмовником. Суть його в тому, що учасники освітньої взаємодії власними словами підводять підсумок основним думкам співрозмовника. При резюмуванні з цілої частини розмови виділяється тільки головна думка. Найбільш часто резюмування у процесі викладання іноземної мови за професійним спрямуванням можна використовувати у таких ситуаціях, як: pair discussions; group discussions; projects; interviews, тощо.

Загалом, резюмування як вид активного слухання, можна використовувати в усіх комунікативних ситуаціях у процесі викладання іноземної мови за професійним спрямуванням. А особливо корисним та ефективним цей вид активного слухання може бути при обговоренні дискусійних питань. Наприклад, коли учасники освітніх взаємодій планують висловити незгоду щодо почутої інформації, ми можемо спочатку виділити у висловлюванні співрозмовника головне та підсумувати сказане. У такому випадку співрозмовникам не доведеться розпорошуватися, приводячи контраргументи, і їм вдасться відповісти на суть заперечення. А ще краще попросити співрозмовника зробити резюме сказаного (тоді він повинен буде позбавити своє заперечення 
від усього другорядного, що значно полегшить процес сприйняття інформації та виконання поставленого завдання).

Висновки та перспективи подальших досліджень. Зважаючи на вищезазначене, ми можемо зробити висновок, що комунікація у процесі викладання іноземної мови за професійним спрямуванням $є$ надзвичайно складним і багатовимірним явищем.

Відтак, сам засіб (спосіб, стиль) комунікації під час навчального процесу стає важливім інструментом спілкування. Тобто зміст отримуваної інформації залежить насамперед від того, наскільки учасники навчального процесу вміло та ефективно використовують усі можливі способи передати а отримати (інтерпретувати) важливу інформацію у процесі вивчення іноземної мови за професійним спрямуванням.

Тож, узагальнюючи все вищевикладене, можна стверджувати, що використання вербальних та невербальних прийомів активного слухання у процесі викладання іноземної мови за професійним спрямуванням виявляється у якісному вдосконаленню комунікації, що у перспективі сприяє:

1) забезпеченню позитивної атмосфери на заняттях з іноземної мови;

2) мінімізації ймовірності конфліктних ситуацій у процесі викладання іноземної мови за професійним спрямуванням;

3) формуванню поваги та довіри між учасниками освітнього процесу.

Отже, активне слухання, за умови системного та цілісного використання, стає одним із важливих способів підвищення ефективності комунікації у процесі викладання іноземної мови за професійним спрямуванням та суттєво покращує його якість.

Здійснена у статті систематизація прийомів активного слухання та визначення способів його використання у процесі викладання англійської мови за професійним спрямуванням сприятиме вдосконаленню практичних підходів до використання активного слухання у професійній діяльності учасників освітніх взаємодій у системі вищої освіти.

Перспективу подальших наукових досліджень вбачаємо у визначенні та обгрунтуванні інших практичних способів удосконалення викладання іноземної мови за професійним спрямуванням у системі вищої освіти.

\section{Використані джерела}

[1] Bean, J. (1996). Engaging Ideas: The Professor’s Guide to Integrated Writing, Critical Thinking and Active Learning in the Classroom. Jossey-Bass.

[2] Гальскова, Н. (2000). Современная методика обучения иностранному языку: пособие для учителя. Москва: АРКТИ-Глосса.

[3] Локшина, О. (2019). Європейська довідкова рамка ключових компетентностей для навчання впродовж життя: оновлене бачення 2018 року. Украӥнський педагогічний журнал, № 3. С. 21-30.

[4] Richards, J. (2005). Communicative language teaching today. Cambridge: Cambridge University Press.

[5] Savignon, S. (2001). Communicative language teaching for the twenty first century. Teaching English as a Second / Foreign Language. M. Murcia. Ed. PP. 12-28. Boston, MA: Heinle \& Heinle.

[6] Тарнопольский, О. (2019). Методика викладання іноземних мов та їх аспектів у вищій школі: підручник. Дніпро: Університет імені Альфреда Нобеля.

[7] Schultz, D. (2009). Eloquent Science: A Practical Guide to Becoming a Better Writer, Speaker and Scientist. American Meteorological Society.

[8] Леонтьев, А. (2003). Основы психолингвистики. Москва: Смысл; Санкт-Петербург: Лань.

[9] Никифорова, Г. (2004). Психология менеджмента: Учебник для вузов. Санкт-Петербург: Питер.

[10] Нестеренко, Л. (2014). Особливості використання психологічних тренінгів у процесі викладання іноземної мови за професійним спрямуванням. Актуальні проблеми державного управління, педагогіки та психології: збірник наукових праць Херсонського національного технічного університету. Вип. 1 (10). С. 107-110.

[11] Нестеренко, Л. (2016). Педагогічні умови розвитку психолого-педагогічної культури викладача ВНЗ. Проблеми освіти: наук. зб. Інституту інноваційних технологій і змісту освіти Міністерства освіти і науки, молоді та спорту України. Вип. 73. С. 200-205. 
[12] Стратегія Національного агентства із забезпечення якості вищої освіти до 2022 року. (2018). Доступно: https://naqa.gov.ua/\%D0\%BC\%D1\%96\%D1\%81\%D1\%96\%D1\%8F-\%D1\%82\%D0\%B0-\%D1\%81\%D1\% 82\%D1\%80\%D0\%B0\%D1\%82\%D0\%B5\%D0\%B3\%D1\%96\%D1\%8F-\%D0\%B0\%D0\%B3\%D0\%B5\%D 0\%BD\%D1\%82\%D1\%81\%D1\%82\%D0\%B2\%D0\%B0/. Дата звернення: липень 23, 2021.

[13] Наказ № 977 Про затвердження положення про акредитацію освітніх програм, за якими здійснюється підготовка здобувачів вищої освіти. (2019). Доступно: https://zakon.rada.gov.ua/laws/show/z0880-19\#Text. Дата звернення: липень 23, 2021.

[14] Наказ № 518 Про затвердження Концепції забезпечення якості освіти в НаУКМА. (2016). Доступно: https://www.ukma.edu.ua/index.php/about-us/sogodennya/dokumenty-naukma/cat_view/1-dokumentynaukma/12-normatyvna-baza-naukma/6-systema-zabezpechennia-iakosti-osvitnoi-diialnosti-ta-iakostivyshchoi-osvity/71-normatyvni-dokumenty?limit=5\&limitstart=0\&order=date\&dir=ASC. Дата звернення: Липень 23, 2021.

[15] Наказ № 610 Про затвердження професійного стандарту на групу професій «Викладачі закладів вищої освіти». (2021). Доступно: https://mon.gov.ua/storage/app/media/pto/standarty/2021/03/25/Standart\%20 na\%20hrupu\%20profesiy_Vykladachi\%20zakladiv\%20vyshchoyi\%20osvity_25.03.pdf. Дата звернення: Липень 23, 2021.

[16] Карамушка, Л. (2003). Психологія управління: Навч. посіб.- Київ: Міленіум.

[17] Орбан-Лембрик, Л.Е. (2002). Основи психології управління. Івано-Франківськ: Плай.

[18] Нестеренко Л. (2019). Робоча програма навчальної дисципліни: Англійська мова (за професійним спрямуванням) для студентів ФСНСТ. Ухвалено на засіданні кафедри англійської мови. Протокол № 7 від 15 квітня 2019 року. Київ: НаУКМА.

\section{References}

[1] Bean, J. (1996). Engaging Ideas: The Professor's Guide to Integrated Writing, Critical Thinking, and Active Learning in the Classroom. Jossey-Bass. PP.36-219. (in English).

[2] Galskova, N. (2000). Modern Methods of the Foreign Language Teaching: a manual. Moskva: ARKTI-Glossa. (in Russian).

[3] Lokshyna O. (2019). Yevropeiska dovidkova ramka kliuchovykh kompetentnostei dlia navchannia vprodovzh zhyttia: onovlene bachennia 2018 roku. Ukrainskyi pedahohichnyi zhurnal, № 3. S. 21-30, Kyiv, Ukraina. (in Ukrainian).

[4] Richards, J. (2005). Communicative language teaching today. Cambridge: Cambridge University Press. (in English).

[5] Savignon, S. (2001). Communicative language teaching for the twenty first century. Teaching English as a Second / Foreign Language. M. Murcia. Ed. PP. 12-28, Boston, MA: Heinle \& Heinle. (in English).

[6] Tarnopolskyy, O. (2019).The Methods of the Foreign Language Teaching in the Higher Education: the textbook. Dnipro: University named after Alfred Nobel. (in Ukrainian).

[7] Schultz, D. (2009). Eloquent Science: A Practical Guide to Becoming a Better Writer, Speaker and Scientist. American Meteorological Society. PP.218-436. (in English).

[8] Leontiev, A. (2003). Psychlinguistics Backgrounds.- Moskva: Smysl; Sankt-Peterburg: Lan. (in Russian).

[9] Nikiforof, G. (2014). The Psychology of management. Sankt-Peterburg: Piter (in Russian).

[10] Nesterenko, L. (2014). Psychological Training Use Key features in the Foreign Language Teaching in accordance with the professional purposes. Key Issues of the Public Administration, Pedagogics and Psychology: the Collection of the Scientific Works of the Kherson National Technical university. Volume 1 (10). PP.107-110 (in Ukrainian).

[11] Nesterenko, L. (2016). Psychological Conditions of the Psychological and Pedagogical Culture of the University Teacher. The Issues of Education: the Scientific Collection of the Institute of the Innovative technologies and of the Content of Education of the Ministry of Education, Science, Youth and Sports of Ukraine. Volume 73. PP.200-205. (in Ukrainian).

[12] Strategy of the National Agency of Higher Education Quality Assurance to 2022. (2018). Available: https:// naqa.gov.ua/\%D0\%BC\%D1\%96\%D1\%81\%D1\%96\%D1\%8F-\%D1\%82\%D0\%B0-\%D1\%81\%D1\%82\%D 1\%80\%D0\%B0\%D1\%82\%D0\%B5\%D0\%B3\%D1\%96\%D1\%8F-\%D0\%B0\%D0\%B3\%D0\%B5\%D0\%BD \%D1\%82\%D1\%81\%D1\%82\%D0\%B2\%D0\%B0/. Accessed on: July 23, 2021. (in Ukrainian). 
[13] Decree № 977 About the approval of the rules of the accreditation of the educational programs in accordance with which the preparation of the higher education applicants is done. (2019). Available: https://zakon.rada. gov.ua/laws/show/z0880-19\#Text. Accessed on: July 23, 2021. (in Ukrainian).

[14] Decree № 518 About the approval of the Concept of the Quality Assurance at NaUKMa. (2016). Available: https://www.ukma.edu.ua/index.php/about-us/sogodennya/dokumenty-naukma/cat_view/1-dokumentynaukma/12-normatyvna-baza-naukma/6-systema-zabezpechennia-iakosti-osvitnoi-diialnosti-ta-iakostivyshchoi-osvity/71-normatyvni-dokumenty?limit=5\&limitstart=0\&order=date\&dir=ASC. Accessed on: July 23, 2021. (in Ukrainian).

[15] Decree № 610 About the approval of the professional standard for the group of the professions «Teachers of Higher Education». (2021). Available: https://mon.gov.ua/storage/app/media/pto/standarty/2021/03/25/ Standart\%20na\%20hrupu\%20profesiy_Vykladachi\%20zakladiv\%20vyshchoyi\%20osvity_25.03.pdf. Accessed on: July 23, 2021. (in Ukrainian).

[16] Karamushka, L. (2003)/ The Psychology of management: Textbook.- Kyiv: Millenium. (in Ukrainian).

[17] Orban-Lembryk, L. (2002). The Backgrounds of the Psychology of Management. Ivano-Frankivsk: Plai. (in Ukrainian).

[18] Nesterenko, L. (2019). The ESP for the Students of the Social Sciences and Social Technologies Faculty. Syllabus. Approved by the English language Chair, Protocol N7, 15 of April. Kyiv: NaUKMA. (in Ukrainian.

Liudmyla Nesterenko, Ph.D. (Public Administration), Associate Professor, Associate Professor of the English Language Department, Humanities Faculty, National University "Kyiv-Mohyla Academy”, Kyiv, Ukraine.

\section{ACTIVE LISTENING AS THE INSTRUMENT OF THE EFFECTIVE COMMUNICATION IMPROVEMENT IN THE PROCESS OF TEACHING ENGISH FOR PROFESSIONAL PURPOSES IN HIGHER EDUCATION INSTITUTIONS}

Active listening as a way to increase the effectiveness of communication in the process of learning English for professional purposes in the Free Economic Zone

The article is devoted to the active listening that is viewed by the author as one of the key instruments aimed at the communication improvement of the foreign language teaching (on the English language example) in the system of higher education. The article describes the key psychological peculiarities of communication in the process of foreign language teaching and the ways of its improvement in the system of higher education. The practical significance of the implementation of the active listening approach into the process of foreign language teaching in the system of higher education is theoretically proved. The key requirements of the curricular and syllabi modernized in accordance with the reforms in the system of education of Ukraine and that are aimed at the integration of the theoretical and practical skills of the learners are thoroughly studied and highlighted. Various attitudes that characterize approaches to listening in the classroom are presented and scientifically evaluated (empathetic listening, critical listening, passive listening and active listening). The scientific and theoretical requirements to the active listening introduction into the classroom (social and psychological as well as cognitive and context) are characterized and studied. The practical suggestions (nonverbal and verbal (grammatical and lexical)) of the active listening introduction into the ESP teaching are presented in the article as well. It is scientifically proved that active listening is one of the efficient instruments of the communication effectiveness improvement in the process of foreign language teaching. The practical outcomes of the active listening introduction into the system of the foreign language teaching are also presented in the article (better nurturing environment in the classroom, better stress resistance, improved conflict management skills, upgraded communication skills, facilitating atmosphere, etc.).

Keywords: ESP teaching; communication; active listening; active listening instruments; empathy; higher education; effectiveness; quality of education. 